\title{
AN OVERVIEW OF THE METHODOLOGICAL APPROACHES TO RESEARCH OF ENVIRONMENTAL LAW AND LEGISLATION
}

\section{Sydor V. D., Kostytska I. O.}

\section{INTRODUCTION}

The dynamics of the development of the environmental relations of the society confronts the science of environmental law with many problems. The destruction of the economic and socio-political system of the Soviet society led to a certain disruption in the research of the methodology of social processes. Rapid reforms of the economic and political system of Ukraine, significant dynamic formation of the new forms of social life require appropriate legal provision that would be based on the modern scientific theory and methodology.

The analysis of the scientific literature reveals the different, often contradictory approaches to the interpretation of both the concept and the essence of the methodology and it characteristics, features and developmental trends in the science of environmental law. It can be explained by the diversity of methodological investigations that differ by their theoretical level, the degree of differentiation of their own methodological problems from the object of its study, and by the author's understanding of the basic methodological research methods and techniques of environmental-legal phenomena.

There is a general opinion in legal literature that the methodology of science should be considered as the study of general principles, ways, patterns of scientific knowledge, principles and practices that are carried out at different levels (philosophical, scientific, specific sciences, methods and techniques). They aim at development of the provisions that give the opportunity to choose tools and to build procedures which will effectively resolve problems and challenges that arise in the process of research. The methodology defines the means of gaining scientific knowledge, which reflects the dynamic processes and phenomena, provides comprehensiveness of information, creates a system of legal information that is based on objective facts. 


\section{Classical Methods and Approaches of Ecological Legal Research}

Environmental methodology contains knowledge about:

1) approaches, principles, methods and techniques which are to be used in studying the sources of law;

2) approaches, principles, methods and techniques of knowledge which should be used in any experimental procedure;

3 ) the content of specific approaches, principles, methods and techniques used for the law sources and the consequences of their development;

4) the way the methods are interrelated in the process of learning and obtaining new knowledge.

The methodology of the legal science is a system of approaches, methods and techniques of the scientific research, the theoretical basis of their usage in the study of the state-legal phenomena.

The basis of the methodology of legal science is presented by such approaches:

1) philosophical and ideological approaches (materialistic or idealistic, metaphysical or dialectical, recognition or denial of the objective social, including state-legal, patterns and possibilities of their studying and gaining true knowledge about them);

2) general scientific methods, that are used in all or most sciences (structural, functional methods, method of transition from the abstract to the concrete);

3) formal logical procedures - analysis and synthesis;

4) group methods that are used only in a particular group of sciences, for example, only in the social sciences (e.g., method of concrete sociological research);

5) special methods that are appropriate for the study of any science subject (interpretation of the legal norms, special techniques summarizing legal practice $)^{1}$.

Methodology is objectively determined by the subject knowledge derived from general conceptual approaches, the level of the scientific knowledge. The methodology is a system of methods, a set of techniquess and activities of research and knowledge about them. Objectively, this system is stipulated by the nature of the phenomena and processes which

${ }^{1}$ Юридична енциклопедія : В 6 т. / Редкол. : Ю.С. Шемшученко (голова редкол.) та ін. / 3-й том “К-М”. К. : Укр. енцикл., 2001. С. 618. 
are studied and which arise from the general methodological state of thescientific knowledge and scientific interests.

A comprehensive and detailed study of the methodological problems of environmental legislation development should be one of the main tasks of the science of environmental law. Methodology of environmental laws is an application of a set of specific theoretical principles, logical and special methods of investigation of the environmental legislation development ${ }^{2}$. The method of study is a mind process that is implemented in a scientific manner and focused on the subject (object) of the research to acquire new legal knowledge in general theoretical and in applied aspects of the study.

There are main methods of scientific research in environmental law:

1) formal logical method that provides scientific reliability of the obtained information and enables to detect inconsistency of certain environmental laws with the realities of social life, as well as contradictions between some norm-legislative acts;

2) formal legal method that guarantees the study of environmental law development problems exclusively in the context of positivism;

3) method of factor analysis, which allows to take into account quantitative and qualitative changes in environmental laws depending on certain circumstances, and also to build factor models needed in the process of legal forecasting;

4) functional legal method which requires the study of environmental law from the standpoint of its tasks and functions;

5) activity method that helps to examine the role, place and meaning of a single norm-legislative act in the environmental legislation;

6) comparative legal method which facilitates the identification of general and special, typical and unique characteristics in the legal regulation of the environmental relations in different countries. It allows establishing a positive experience of legal regulation of environmental relations abroad;

7) sociological method which enables to study and consider the general laws of social development, economic analysis, political, social, psychological, demographic and other phenomena in the society in the process of developing regulations of the environmental laws;

8) historical and legal method that provides succession of environmental laws development, allows to reveal the positive and

2 Гетьман А. Методологічні засади становлення правових основ охорони довкілля. Право України. 2011. № 2. С. 14. 
negative features of historical sources of environmental laws and helps to establish the consequences of their impact on the environmental relations;

9) systematic and structural method that allows to regard the environmental legislation as an orderly, coherent, logically structured set of normlegislative acts aimed at regulating land relations;

10) logical-semantic method based on tracing the formation of specific conceptual-categorical system of the environmental laws;

11) prognostic method that makes it possible to make science-based forecasts of the environmental laws development. Formal-logical method is one of the most traditional ones in the legal science ${ }^{3}$.

It requires from the researcher a certain order of study, consistency, credibility and accuracy. It is essential to follow formal-logical requirements to ensure the reliability of the received information. This method allows identifying the discrepancy between legislative norms and the realities of the social life, the contradiction between the acts, etc. It is necessary to consider the peculiarities of the application of the formal legal method while studdying the environmental law because of its usage has both advantages and disadvantages.

Studies of the environmental law developmental problems exclusively within the context of positivism can lead to a simplified view of the legal phenomenon because only the features of legal phenomena secured by the legislator could be deeply scientifically analysed using this method. Therefore formal legal method should be used only in combination with other special legal methods. Functional method requires the study of the law sources through their functions, several functions or functional system. The functional nature of the system of the law sources stipulates the methodological grounds of their study, namely, the need to study the activities of each component of the system, the interaction between them and other systems.

The system of law sources is dynamic; it is constantly evolving because of its inherent internal and external conflicts, operating in an external environment that defines and develops it, determines the direction of its operation. The method of functional legal analysis is important both for the general theoretical plane, and for the determination of the effectiveness of environmental law. This is the method of systematic study of the effectiveness of the environmental-legislative norms in the process

${ }^{3}$ Пархоменко Н. М. Джерела права: проблеми теорії та методології : монографія. К.: ТОВ “Вид-во “Юрид. думка”, 2008. С. 38. 
of its implementation, which considers the quality and the degree of the implementation of the functions specified in the legislative acts (legal norms) which regulate the environmental relationships.

The application of the functional legal method will help to orient in the legislative acts, practical materials of its implementation, will create favorable conditions for the development of scientifically based recommendations for the improvement of the environmental legislation and the mechanism of its application.

Activity method involves the study of law sources through their action. These techniques are linked, but not independent. Application of the activity method helps to identify the role, place and the importance of law sources in the legal system.

Comparative legal method helps to take into account existing international experience, models of organization and functioning of the environmental sources, individual norm-legislative acts, analysis of the legal comprehension concept. Comparative legal method is used to determine common and different features of the law sources within one or more legal systems, by comparison, discrimination on any ground or characteristics. The decision of Ukraine to enter the European space requires adapting of the EU legislation, which in its turn makes it mandatory to use the comparative method of the research ${ }^{4}$.

Comparative legal studies are rather useful for the implementation of legal reform in the states that are at the transformation stage of their development (such as Ukraine), as it enables to go beyond dogmatic debate within the national law and to offer new methodological approaches, taking into account national experiences. Special methods of comparative legal research are represented by compare (based on similar material properties of objects) and contrast (standard selection among objects, which can be the most effective model of regulation in specific circumstances).

Critical method makes it possible to assess the specific provisions regarding the prospects and trends of the environmental legislation development that allows to reconsider earlier developed theoretical construction in a new way, to get rid of the outdated approaches and to detect errors in the doctrinal arguments of some scholars.

\footnotetext{
${ }^{4}$ Малишева Н. Р. Гармонізація екологічного законодавства в Свропі : дис. у формі наук. доповіді на здобуття наук. ступеня д-ра юрид. наук; Ін-т держави і права ім. В. М. Корецького НАН України. К., 1996. С. 18.
} 
System-structural method integrates systemic analysis and structural functionalism. It represents two aspects of a systematic approach to the analysis of the operation and development of the law sources. Systemattic analysis is essential for the study of law sources and is stipulated by the imposed problem itself. The system of law sources in some way requires an orderly, coherent, logically constructed set of the law sources.

The usage of this method allows to find and fully analyze the mutual influence of the law sources, to draw a conclusion about the effectiveness or ineffectiveness of the functioning of the law sources system in general and in Ukraine in particular. Predictive method is a set of techniques that allow to make scientifically-based predictions about the future development of law sources. A separate aspect of the research methodology of the law sources is the relationship between the phases, stages, which has a hierarchical character, namely: each next consequent stage uses materials, knowledge gained at the previous stages, despite the fact that the basis of the analysis is only objectively-true knowledge, this relationship between stages leads to the hierarchical relationship between the methods used at these stages.

Science which is based on a certain set of concepts of various sciences is a methodologically properly structured science. It serves the basis for the true methodological law structure and allows to carry out a profound methodological analysis, to design a new methodological strategy based on co-evolutionary relationship between human and nature, anthropology, synergy and other modern sciences.

During the last century the classical methodology, built on rational and objective approach, through nonclassical (with its freedom of choice and subjectivity), came to the post-classical (postmodern) methodology, which is characterized by the recognition of irrational and pluralist approaches. The deidealization has replaced ideological standards that had prevailed in the national methodology for almost the entire twentieth century. That's why the greater ideological importance is focused on human values and respect for the principles of humanity, human dignity, freedom, justice, mutual responsibility of the state and the individual. Till now the dominant ideological monism has limited research by the dogma of law.

Future law science seems primarily responsible for studying two basic fundamental key problems: the methodology of law and cooperation with other natural, technical and social sciences. It's time to finally understand that the content of the development of methodological law problems doesn't only involve self-understanding of the science, the improvement 
of the legal culture of thinking, but it also gives the future research powerful cognitive tools that allow to deeply penetrate into the unknown, not yet investigated layers of the legal reality. An important methodological feature of the study of the environmental law is the usage of an interdisciplinary approach. The Environmental law as a science is a structured knowledge of the environmental norms, forms and methods of forming the environmental law awareness and ways to improve it. It also includes: legislators' ideas about the subject and method of the given branch of legal knowledge, sources and determinants of their formation, the place of environmental law in the jurisprudence.

The essential point that determines the nature and characteristics of the formation and development of the environmental legal knowledge is the awareness of the connection of environmental rights, not only with other branches of legal science, but also with other social sciences - sociology and philosophy that define the methodological research. In particular, the philosophical part is not only an external means of theoretical justification, but it also determines the methodological orientations and inner meaning of most theoretical concepts and the knowledge. National and foreign philosophical, economical, environmental, agricultural, biological and other doctrines, as well as the legal doctrine of the environmental usage are the basis for the economic, social, public legal, demographic, spiritual and cultural development of the people and conservation of the environment. In the relationship people - nature an exclusive role belongs to the environmental as an object of legal regulation of social relations are caused by its objective physical characteristics and functions in nature, economy, society, and the subjective legal qualities that define it as an object of environmental land law.

Environmental relations develop on the basis of the economic consequences, and the environmental laws influence their formation and development. While regulating with the help of the developed norms of the environmental legislation, the reverse process of transferring regulatory requirements into an actual behavior and into real social environmental relations.

Updating of the problems of using sociological approach in environmental law science is stipulated by the role of this area of law in theory and practice of state functioning. One of the real ways to overcome the crisis in modern jurisprudence is the development of the sociology of the law, the study of law as a phenomenon of our civilization through the prism of "life", abstract legal norms due to its application, fulfillment and 
realization by the subjects of the social relations. Environmental legislation as a specific regulation tool significantly affects the selection of means and methods used in the process of regulating environmental relations.

In a legal state the legislative activity involves correspondence between legality and law expediency taken on behalf of the state organized society. They necessarily take into account the interests of each individual, which are implemented by all legal entities and primarily by the state itself. Since the law as a whole is intended to assist the legislator in the development of scientific bases of society and sciencebased recommendations for the improvement of this administration, it can be argued that the task of legal science is to assist the legislator in the formulation and adoption of legal norms.

\section{Modern Approaches to Environmental Law Medology}

Nowadays environmental law is developing rapidly and the science of the environmental law should aim at facilitating this process by solving current and future problems of improving the environmental legislation. The social function of the legal science require scientists to develop effective mechanisms that can influence the situation in law enforcement. In order to adequately respond to the current need for integrated research of analytical and applied nature, it is necessary to turn theoretical understanding into the generalization of the social and judicial practices, considering the legislative dynamics and changing economic and political conditions.

This approach does not reduce the importance of the fundamental works. It primarily deals with the fundamental nature of the legal science, the attempt to close the gap between theory and practice. The Environmental law today is experiencing a period of the accumulation of the theoretical knowledge, but its isolation from the needs of the legal and social life may have negative consequences for the entire industry. Legislative activity is based on the needs of objective, independent from the people's will economic laws. Implementing the unification of the old and developing the new environmental legislation is necessary to take into account the objective nature of the economic laws, correlation between economic and legal laws question which leads to the subjective idealism.

The current level of the environmental law science and legislative activity poses before the science of the environmental law the problem of improving the methods of the empirical research in the field of 
environmental law norms application with the goal to identify their efficiency and find ways to improve environmental legislation, bringing it in compliance with the changing socio-economic conditions of our society. In this regard, considerable importance is attached to the sociological trend in land environmental science, which involves the study of actual social relations in environmental law, analysis of the relationship between legal norms, legal relationship and actual environmental relations. In particular, the methods of empirical research in environmental law represent surveys and questionnaires of environmental law specialists, observation method, etc.

The socialization of the law and legal knowledge has become one of the most important directions of adapting domestic law to the current challenges. The man as a carrier of inalienable rights and freedoms, which have to determine the content and direction of the state functioning, can now be seen outside the legal science ${ }^{5}$. Only with awareness of the social foundations of rights, the legislation may be considered in the context of ensuring and protecting the rights and freedoms of a man and a citizen, functioning of a legal state and a legal culture. On this basis the sociological approach to a law as a theoretical concept that has social nature, different from the usual application of the jurisprudence methods of empirical sociological research to confirm certain theoretical conclusions, is formed. It is necessary to conduct in-depth analysis of the existing environmental relations which require or may require the legislative regulation. Since actual social relations are rather interchangeable, unstable, it is important not only to identify their current system, but also to find out the trends of their development. This analysis makes it possible to build a model of legal regulation of relations in the future, or, in other words, to predict the development of the environmental law, to prepare the creation of appropriate norms and institutions.

The main peculiarity of a legal prediction is the recognition of the fact that the law is always evolving to reflect changes in social life, in actual people's relations. It is possible to predict the development of law only on the basis of known or projected society development. However, the prognostic nature of the reflection in the law has its limits which can be divided into social, epistemological and the legislative rights themselves.

5 Петришин О. Проблеми соціалізації права та соціологізації правової науки. Право Украӥни. 2011. № 8. С. 138. 
Social boundaries are expressed in the fact that the legislation should not only accurately reflect the future development of social relations, but also take into consideration a real social, specific historical opportunity to achieve it. Socio-legal prediction can be fruitful only when it is based on the study of the general laws of the social development. It is necessary to analyze the economic, political, social, psychological, demographic and other phenomena in society, which together determine the possibility of a public life regulation to reveal the objective laws of these phenomena ${ }^{6}$.

The fundamental methodological problem of environmental law and legislation is the subjective factor and the complexity of legislators' understanding of the legal environmental processes and phenomena. A man creates legislation that would adjust environmental relations, and it seems that the existence of this law depends on the will of a person who has made it. However, the trajectory of environmental legislation often goes beyond the goals and objectives of its creators. The environmental law science is beginning to use synergy methodology, a new science that studies self-organizing, random processes. These methodological ideas allow a better understanding of the genesis of the environmental legislation, some of its legal institutions.

Environmental relations are to be investigated according to the laws of self-organization and self-development. They have a historic status, stages of growth and development, periods of stability and change. Historical status of the environmental relations helps determine the specificity of different stages of formation and functioning because their development depends on the stages of the social development. The spread of synergy as an interdisciplinary research method marked the transition to Postclassical development of the science.

Synergetics explores various open systems capable of selfdevelopment. This system is estimated as a nonlinear, characterized by a special mechanism of bifurcations, irreversibility and uncertainty. Random fluctuations imbalance the system and as a result, it loses its stability. Due to the positive feedback, the fluctuations are increasingly amplified and can lead to bifurcation - the destruction of the previous system and its transition to a new state. Switching to a higher stage means selforganization. Instability is no longer considered as something destructive

\footnotetext{
${ }^{6}$ Костицький В.В. Соціологія права: науково-теоретична спадщина Свгена Ерліха і проблеми розвитку сучасної наукки: Монографія. Ін-т законодав. передбачень і прав. експертизи. Вид. 2-ге. Київ : Коло, 2016. С. 87.
} 
and negative; it is regarded as a condition of stable and dynamic development. The emergence and development of the idea of the imbalance, non-linearity and instability proved multivariate ways of development ${ }^{7}$.

As a result, modern system of thinking is more likely to take into account the dynamics in the study of stability problems. Synergetic understanding of the development and structure represents a new stage of methodology.

Productivity of synergy ideas is the synthesis of the subjective and objective approaches. The role of synergy provokes internal growth, selforganization of the environmental and legal knowledge, its inner reorganization. New information about the constructive role of a chance in a social development allows to clarify the subjective factor of reforms, and to take into account both logical cause-effect relations and random relations. Possibilities of synergy are extremely broad in the study of legal processes.

Synergistic methodology is relevant due to the increase of the number of the regulations, widening of the range of their action and consolidation of them with the disparate, sometimes contradictory public interests. Synergistic methodology develops the concept of selforganization rights, emphasizing the growing danger of the disruption. It points out the cause of unpredictable reactions of subjects in their legal relationship. Synergetic approach allows us to take a fresh look at the issues of overcoming and eliminating inconsistencies in the regulations and other legal acts. The research is driven largely by the structural and systemic approach. The specificity of synergetic approach lies in its completion by a large unit that examines patterns of inconsistency of the law. In addition, scientific approach using synergy ideas enables us to master qualitatively a new group of methods and principles of the research.

Synergistic research approach to legal theory leads to the conclusion that the synergistic ideas can help "uncover" significant resources for improving the efficiency of the regulation without any special costs and, what it is important, to minimize the costs of limited legal means and methods. On the way of the promotion of new ideas in law, the legal science should reject the domination of the monistic law comprehension. Its roots are so deep that many researchers ignore the fact, and some

7 Князева Е.Н. Синергетика: начала нелинейного мышления. Общественные науки и современность. 1993. № 2. С. 13. 
directly deny any other spheres of law life except legal norms based on the traditions of "pure" law. This leads to a conclusion about the excellency of the standards established by the legislator, where judgments are made within the space, limited by the regulatory forms ${ }^{8}$.

The necessity of transcending law dogma and consideration of its other faces and forms of existence is dictated by the objective needs of the environmental law as a branch of law, and as a science. This dogmatic approach is not rejected, but it must be used in the combination with other approaches, such as natural, social and others. Only then environmental legislation will be available for public understanding as a regulator of environmental relations.

The value of the current environmental law and its highest purpose is to create conditions for the realization of the natural and inalienable environmental rights. Environmental issues should be investigated according to the laws of selforganization and self-development. They have historic status, stages of growth and development, periods of stability and change. Historical status of environmental relations helps determine the specificity of different stages of formation and functioning, because their development depends on the stages of social development.

Ukraine has rich nature, which can be a strong base for the solution of socio-economic problems in the country. That's why today the most acute problems are concentrated in the sphere of the environmental and land relations. Instead of the long absence of the variety of forms of the possession the process of the development and implementation came with the equality of the land ownership. During the transition period the main emphasis in the theory and practice lies on the recognition of the necessity of the private ownership of land and the formation of a new stratum of landowners. However, the transformation of land relations, along with the positive effect of the development of different forms of land ownership, have found some dangerous trends in the national economy, which ignore the role of the state. Acute problems of the irrational land usage, the question of the land taxation, regulation of land relations in a market economy pose new methodological, conceptual and theoretical research tasks in the field of the land policy. Under the new conditions, modern Ukraine needs complete and effective land relations, formation and regulation of which are the purpose of land legislation.

${ }^{8}$ Сидор В.Д. Методологічні основи земельного законодавства України. Наукові записки Львівського університету бізнесу та права. Львів : ЛУБП, 2010. Вип. 5. C. 168 . 
The concept of the objective and tasks of the environmental legislation and law are sometimes are clumped together. It is necessary to compare these concepts and to determine the place of each of them in the environmental legislation and law, as well as implications of their development. Furthermore, in the absence of a clear, systematic understanding of the objective and tasks of the current environmental legislation and law it is important to analyze the existing definition of the objective and tasks, to give their classification and suggest precise formulation for further development of the environmental laws. This study is becoming outmost important against the general background of the legislators' decreasing interest to clarify the objective and to set tasks. It is known that the objective shows the value and meaning of the existence of the legal means and focuses on the values that underlie the legal policy of a particular state.

Outlining the scope of freedom of behavior of the environmental relations, the mechanism of environmental legislation and law gives a possibility to differentiate and integrate a variety of interests in environmental purchase and the usage of their useful properties which are formed in a society; to resolve in a civilized way environmental disputes, to find compromise in the process of solving conflicts. This is the general social essence of the environmental law - on one hand, while establishing the basic law of the environmental rights and freedoms, the government gives a possibility to act, and on the other - restricts the freedom of the individual, setting the rules of proper (or, conversely, improper) behavior.

The rights of citizens determine the meaning, content and application of the laws, the activities of the legislative and executive authorities, local authorities and provide justice. The constitutional duty of the legislative, executive and judicial authorities to respect and ensure respect for human civil rights is one of the most important legal principles to protect them. Environmental and legal rules are aimed to create intolerance for violators of the environmental law, increase respect for nature and its resources. Environmental legislation establishs behavior standards and attributs or prohibits certain actions, contributes to public justice. The correlation of the objective and tasks of environmental laws and rights lies in the secondary character of tasks as to the purpose because tasks are defined by and subject to objective laws of the nature. The task of the environmental legislation and laws is one of the varieties of social problems of society. Such tasks are aimed to achieve the goal of the legal regulation of the environmental relations. 
Prerequisite for the development of the environmental legislation is the study of the effectiveness of its regulations. The problem of improving the environmental legislation at present is of particular importance, due to the great difficulty towards democracy and development of the law. Hence the urgency is the research directions of the environmental legislation of Ukraine, establishing its constitutional provisions and other conditions of formation of the law, the development of the legal principles and structures to ensure the stability of the environmental policy and legal protection of human and civil rights. The legal regulation of the public environmental law plays an important role in this. Creating laws and regulations regarding the use and protection of nature, the state establishes universal rules of conduct and ensure their implementation, brings order and organization in the society, replacing outdated environmental public relations, improving existing and developing new ones. As a result of the legislative activities of the state normative and organizational and legal guarantees of rights are created, on which the establishment of law and order in the land sector largely depends on.

The concept of efficiency of the environmental legislation can be seen as a set of features that characterize the formal legal perfection of the environmental regulations, as well as properties that contribute to the most optimal regulation of the environmental relations according to the purpose and functions. The effectiveness of the legislation is interpreted in the legal literature as the ratio between actual results achieved and the purposes for the achievement of which the relevant legal rules were adapted. The purpose of the legal norm is defined by the measurement of the efficiency that can be applied in the environmental law while studying its effectiveness. Exploring the effectiveness of the legislation can be studied as an internal quality of the legal decisions and their impact on the social relations.

The standard evaluation of the legal norms is the purpose of the norm, since objective standards accumulate social interests, compliance with norms of the social needs, their relationship to other rules of law. The problem now is the inefficiency, imperfection of the mechanism to ensure citizens' rights to nature objects. The ability of the legislation during its operation and development to create the conditions for maximum satisfaction of the basic needs and human interests has been reflected in the notion of the social essence of the legislation. According to the social purpose legal norms are designed to ensure recognized by the society and law, which are expressed in the Constitution of the state and other sources 
of freedom, equality and justice of a person, team and the people in the guaranteed by the Constitution of Ukraine rights and responsibilities regarding the use of the natural objects to meet private and public needs and interests.

This environmental legislation of Ukraine does not exclude the possibility of natural rights to the natural objects, if such rights for various reasons have not been legislated, but their implementation is recognized by the society and are not contrary to the laws of the state and the rule of the supremacy of the law. Therefore, the quality and efficiency of the environmental legislation of Ukraine is largely dependent on how fully and timely state ensures the natural rights of certain subjects on the natural objects, provides equal and fair conditions for the implementation and protection of such rights by establishing them in the legislative norms.

An important problem is the efficiency of the regulations of the environmental legislation. It requires a higher level of the quality of their implementation and the existence of the consistent mechanisms to ensure existing regulations. The task of the quality drafting of the new regulations of the environmental legislation becomes of the great importance. After all, how effectively adopted legal act affects the regulation and development of the public relations, primarily depends on the quality of the content of its specific provisions formulation of which mainly occurs during the development of a legal act.

In the environmental law the determination of the effectiveness of the environmental law is particularly important because of the complexity of the regulated relations. Given that the regulation of the environmental relations is the establishment of a certain behavior of their object - the earth, one of the effectiveness indicators of the environmental law may also be a qualitative state of the object, and in some cases it depends on the requirements stipulated by the environmental legal norms. Therefore, the state of the object itself may indicate an achievement or failure of reaching the goal of the legal norms.

Efficiency of the environmental legislation of Ukraine depends on a set of conditions, required not only by the quantitative, but primarily by the qualitative approach to reform the environmental laws of Ukraine to improve its efficiency. The effectiveness of the legal regulation of the environmental relations is of great social importance. The main criterion of the efficiency of the environmental legislation is the extent of current environmental and legal norms guarantying the rational usage and complex protection of natural objects. 
Efficiency of the environmental legislation of Ukraine is largely dependent on the continued improvement of the environmental law. Various legislative performance criterias are developed in the legal literature. The basic criterion of effectiveness is reaching the goal of the legal regulation, it can be called the result of the regulation. This result is dependent on the object of regulation. There are economic and legal resulst of these actions.

Economic result of the regulation may be called objective because it reflects the economic viability of the law. Only those legal rules that meet the objective economic laws, can give the desired economic result in the process of the regulation. Economic result of land legislative regulation depends primarily on the quality of the environmental laws and their proper application.

It should be noted that the use of economic criteria in evaluating the effectiveness of the environmental laws should be applied depending on whether the natural object is used as a means of production or as a spaceterritorial basis. An important criterion of the effectiveness of environmental legislative regulation is the legal result. It describes the impact of the regulation on the consciousness and behavior of the environmental relations participants in terms of precise and strict application of the law; shows how the resulting regulation strengthens the legitimacy of the area of environmental law or how the environmental law promotes justice for the participants of the environmental relations. The legal outcome of the legal regulation is related to the economic performance, because the favorable economic result is a proof of a positive effect of legal rules on the minds of the business relationships.

The criterion of the efficiency of the environmental legislation of Ukraine is the following qualitative state of the settled norm legislative regulations of environmental relations, that indicate that the goal of environmental legislation has been achieved. The evaluation of the effectiveness of the environmental legislation requires a comprehensive analysis of its formal and substantive legal issues. One of the criterias of an effective legal act as the main element of the legislation is its legal correctness that avoids inconsistencies of the environmental legislation and ensure its unity.

The high quality level of the environmental law is ensured by a number of factors that can be divided into material and specially legal. Tangible factors include sustainability of socio-economic and public policy linkages, timely legislative response to the critical processes taking into 
account the perspectives of the nature of their development, the objectivity and validity of the changes in the environmental relations, forecasting the need for their legal mediation in the future. Specially legal factors include correspondence of the environmental laws of the Constitution of Ukraine, publishing of the subordinate norm legislative acts based on the law, the perfection of the legislative technique, legally competent usage of the adopted legal act. In determining the efficiency is important to consider not even the goal of the laws, but the interests (whose interests the specific regulation is targeting). These issues must be fundamentally solved in the development of the regulation and have the necessary economic and legal justification.

The identification of the interest depends on the need to meet the needs of particular social groups, classes or individual segments of the population and the possibility to meet these needs through activities of these entities, which is a model, the main components of which can be regarded as the most important elements of performance:

- social needs, which are attempted to meet by a particular regulation;

- legal means, their quantity and quality;

- their ability to meet social and legal means necessary confirmed in the normative act;

- the future directions of the improvement of the legislation in order to meet social needs through legal means.

The main criteria of the project quality regulations are:

- compliance with the provisions of the draft of the Constitution of Ukraine and the regulations of a higher power, compliance with the requirements of the draft of the international legal acts ratified by Ukraine;

- inadmissibility of a restriction or violation of the provisions of the draft of the legal rights of man and citizen, conformity of the draft objectives and the goal to achieve;

- the absence of contradictions between the project fundamentals and the related norm legislative acts of the same legislative power;

- the correspondence of the legal form, which is expected to enforce the implamentation of the project, to the value of the public relations in the settlement;

- forecasting of the real legislative mechanism to ensure effective legal creation of the emerging acts.

Systematic analysis of the environmental legislation of Ukraine, based on the study of legal acts regulating the environmental relations, assessing 
the existing scientific approaches and concepts, enabling to assess the significance of various factors of the determined system of environmental laws, their interrelationships, determining the priorities of the industry legislation makes it possible to prepare a set of recommendations for improving the efficiency of the environmental legislation of Ukraine. Efficiency of environmental laws means matching the result of their influence and goal to the objectives of the environmental legislation.

The criterion of the efficiency of the environmental legislation is a qualitative state governed by the regulations of the environmental relations, that indicate that the goal of the environmental legislation is achieved. To improve the efficiency of the environmental laws necessary informed scientific advice based on relevant empirical studies are needed. It is important to improve the system of natural object usage and the legislation to ensure its implementation. Of particular importance is the question of the improvement of state control over the environmental usage and protection. Interests to improve the environmental laws require improvement of the courts and prosecutors' activities implementing of the environmental law, civil law, administrative law and criminal sanctions in case of violations of the environmental legislation.

Promising trend to improve the environmental law efficiency is to improve the law enforcement practices that should be done by the introduction of environmental law procedural norms, which ensure the proper application of the law in practice; to introduce the economic incentive measures for the proper performance of the subjects of the environmental relations duties.

Research of the legal factors of the effectiveness of the legislation is related to the necessity to analyze such theoretical issues as the legal consolidation of the dominant society's needs:

- certainty of substantive lawmaking authority;

- certainty of limits of the legal regulation;

- dependence of the lawmaking activity on the objective conditions of the society development;

- change of the scope and type of the regulation;

- peculiarities of the lawmaking as a result of the creative process;

- the systematic nature of the legislation;

- the quality of the legislation; perfection of the legal technique;

- clear definitions of the types of legal liability following the violation of the regulatory requirements, the mechanism of their implementation. 
The subjective certainty of the regulation directly affects its legal effectiveness. The effectiveness of the hierarchical structure of the legislation depends on the subjective characteristics of the society relations, consistency of the acts that compose it, and identification of the trends and tendencies of its development. One of the most important tasks of lawmaking in the usage and protection of natural objects is passing the laws of the high legal quality. Today, however, the quantitative parameters of the environmental legislation precede over the quality. The basis of updated environmental laws should be qualitative laws, so you need scientific support in the process of the lawmaking of the environmental legislation. The problem of ensuring of the the legal quality of laws is directly related to the task of providing reliable legal protection of persons in the area of the environment.

Various defects of the environmental laws reduce their effectiveness and provoke law enforcement errors that are often expressed in the violation of the environmental rights. The quality of the environmental laws is a stable set of qualities of the instrumentally legal, technical and legal characteristics of certain laws, all of which create the prerequisites for the effective environmental legislation in accordance with its goals and objectives. The quality level of the environmental laws can be determined as a result of the analysis of the degree of compliance with the claims of legal technique to create acts of environmental; giving the participants of environmental relations means of the legal protection of the environmental rights; the establishment of the mechanism of the implementation of the prescriptions of the environmental legislation; the quality of the legislative regulation of the jurisdictional legal means.

The effectiveness of the provisions of the environmental legislation under legislative activities can be defined by: the compliance with the rules of the legal technique in the process of the law-making and consistency of the environmental norms in the acts of the environmental legislation and other branches of the law, compliance with the present standards and the development of the social relations, which lay the legal prescriptions of the mechanisms that could actually function in a market economy. The effectiveness of the legislation depends not only on subjective but also on objective factors. For their acceptance the study of existing relations must precede the implementation of any acts, the possibility of their regulation by the laws, and the right choice of the most perfect forms of it. 
To comply with the legislation the following objective factors are needed:

- to explore various social factors that contribute to the legal regulation of the correspondent relations;

- to identify and take into account interests of social formations while developing the acts;

- the usage of the appropriate scientific achievements;

- a performance of the comparative analysis of the act with similar regulations of other states.

It must be noted that the law-making bodies in their activities do not always focus on the existing system of the environmental legislation of Ukraine. As a result, they have passed new environmental laws, which are inconsistent sometimes with current and may contain conflicting legal requirements.

Imperfection of some separate legal structures and, as a result, law enforcement practices, generate flaws that distort the overall substantial load regulations that establish mechanisms for the usage and protection of nature in Ukraine. Implementing of a strategically motivated, balanced legislative activity is impossible without a country-wide comprehensive analysis of the environmental relations, efficiency of the environmental laws and their application on practice. Modern attitudes to the current environmental laws at all levels of government and society can be described as the perception of an extremely complex, contradictory, incomplete and unsystematic array of laws that do not meet social needs, legislator's designs, and most importantly, the expectations of the citizens.

In connection with this objective it is necessary to create in Ukraine a complex mechanism of the current environmental legislation assessment and its compliance with the interests and objectives of the society and the state. To reduce the extent of the imbalance of the mechanisms of adopting and implementing of the environmental legislative decisions the monitoring system of environmental laws and law enforcement practices is created. It is necessary as a tool for evaluating the effectiveness of the reforms as a mechanism that facilitates timely response to the inadequate regulation of the environmental relations and problems of the law enforcement.

The monitoring of the environmental legislation has become a necessary element of the law-making authorities in order to analyze, control and improve the environmental legislation to bring it into conformity with the provisions of the Constitution of Ukraine. In this 
regard, monitoring of the environmental legislation is seen as a systematic, integrated activity of public authorities, the scientific community, civil society and community organizations for assessment, analysis, synthesis and prediction of the environmental laws and practice. The purpose of the monitoring is to improve the quality of the legislation in the field of regulations of the environmental relations, the improvement based on legislative and enforcement activities of the adoption and implementation of the environmental legislative decisions, respect for and protection of the environmental rights of the citizens. Application of the monitoringof the environmental laws will favor a timely elimination of the outdated rules and regulations, adaption of the amendments to existing regulations and so on. To increase the efficiency of the monitoring of the environmental laws will allow the development of a common methodological basis for the monitoring of the development of scientifically based indicators of the monitoring of the environmental legislation, active usage of the monitoring capabilities of scientific organizations, active usage of the international experience and so on.

In our opinion, the practice of the monitoring of the environmental legislation should expand the range of research methods - the study of documents, comparative analysis, statistical analysis, polls, method of legal expertise, experiment more. But currently studying of the documents and comparative analysis are seen as preferred methods. The monitoring system of the environmental laws should contain the necessary information about the development of the environmental legislation of EU and other foreign countries in terms of the usage of their positive experience. The monitoring system should include: thesaurus of the basic concepts and definitions used in the acts of the environmental laws; framework of the correspondent laws and acts applicable to the regulations; draft laws and subordinate acts that are under development and adoption; the database of the state enforcement activities with regard to judicial and administrative practice of the environmental legislation.

\section{CONCLUSIONS}

At present time there is an objective need for a comprehensive, systematic approach to the legal institution of the monitoring of the environmental legislation. Monitoring in the field of the environmental legislation is an innovative institution of governance and the development of the civil society. Based on the synthesis and analysis of its results the decisions in the sphere of environmental relations can be developed 
promptly, efficiently and effectively implemented. The establishment of a system for monitoring of the environmental laws is a necessary tool to ensure a proper quality of the government decisions on the basis of the development and consolidation of the experience that is already in the monitoring legislation. The creation and development of its new branch forms should be aimed to ensure the development and adoption of the common decisions by the legislative and executive powers in the process of the legislative activity.

Activation of lawmaking, as observed in recent years, along with its positive moments, adversely affected the structural organization of the modern environmental legislation of Ukraine. It does not ensured strict adherence to the principles of the system of the environmental laws, which leads to disruption of its internal logic. There have been numerous violations of the constitutional procedure of the adoption of laws and regulations, legal technology. The preparation of the norm legislative acts is mainly based on the intuition and personal experience of developers, rather than strictly established uniform rules or clear, science-based rules. This approach leads to deficiencies in the rule-making activity, which sometimes can not be fully corrected while adapting norm legislative acts.

\section{SUMMARY}

The paper is devoted to comprehensive and detailed study of the methodological problems of environmental law and legislation. The author substantiates that environmental legislation as a specific regulation tool significantly affects the selection of means and methods used in the process of regulating environmental relations. The system of approaches and methods in environmental law and legislation is analized. The paper emphasizes on such an important methodological feature of the study of the environmental law as the usage of an interdisciplinary approach. To author's opinion the socialization of the environmental law has become one of the most important directions of adapting environmental legislation to modern challenges. It is proposed to design a new methodological strategy based on co-evolutionary relationship between human and nature, anthropology, synergy and other modern sciences. Main legal factors of the environmental legislation effectiveness are investigated. The author proves that various defects of the environmental laws reduce their effectiveness and provoke law enforcement errors that are often expressed in the violation of the environmental rights. 


\section{REFERENCES}

1. Юридична енциклопедія : В 6 т. / Редкол. : Ю. С. Шемшученко (голова редкол.) та ін. / 3-й том “К-М”. К. : Укр. енцикл., 2001. С. 618.

2. Гетьман А. Методологічні засади становлення правових основ охорони довкілля. Право України. 2011. № 2. С. 14.

3. Пархоменко Н. М. Джерела права: проблеми теорії та методології : монографія. К.: ТОВ “Вид-во "Юрид. думка", 2008. C. 38 .

4. Малишева Н. Р. Гармонізація екологічного законодавства в Європі : дис. у формі наук. доповіді на здобуття наук. ступеня д-ра юрид. наук; Ін-т держави і права ім. В. М. Корецького НАН України. К., 1996. С. 18.

5. Петришин О. Проблеми соціалізації права та соціологізації правової науки. Право України. 2011. № 8. С. 138.

6. Костицький В. В. Соціологія права: науково-теоретична спадщина Євгена Ерліха i проблеми розвитку сучасної науки: Монографія. Ін-т законодав. передбачень і прав. експертизи. Вид. 2-ге. Київ: Коло, 2016. С. 87.

7. Князева Е. Н. Синергетика: начала нелинейного мышления. Общественнье науки и современность. 1993. № 2. С. 13.

8. Сидор В. Д. Методологічні основи земельного законодавства України. Наукові записки Львівського університету бізнесу та права. Львів: ЛУБП, 2010. Вип. 5. С. 168.

\section{Information about the authors:} Sydor V. D., Doctor of Law, Professor at the Department of Constitutional, Administrative and International Law, Kyiv Institute of Intellectual Property and Law, National University “Odesa Law Academy”

Kostytska I. O.,

Candidate of Law Sciences, Senior Researcher, Deputy Head of the Department of the Institute of Legislation of the Verkhovna Rada of Ukraine ORCID: 0000-0003-2336-1426 